\title{
Alternative somatic cell count traits exploitable in genetic selection for mastitis resistance in Italian Holsteins
}

\author{
T. Bobbo, ${ }^{*}$ M. Penasa, ${ }^{*} R$. Finocchiaro, $\dagger$ G. Visentin,$\dagger^{1}$ and M. Cassandro* \\ *Department of Agronomy, Food, Natural resources, Animals and Environment (DAFNAE), University of Padova, Viale dell'Università 16, \\ 35020 Legnaro (PD), Italy \\ †Associazione Nazionale Allevatori bovini della razza Frisona Italiana (ANAFI), Via Bergamo 292, 26100 Cremona, Italy
}

\section{ABSTRACT}

The aim of the present study was to characterize alternative somatic cell count (SCC) traits that could be exploited in genetic selection for mastitis resistance. Data were from 66,407 first-parity Holsteins in 404 herds. Novel SCC traits included average somatic cell score (SCS, log-transformation of SCC) in early lactation (SCS_150), standard deviation of SCS of the entire lactation (SCS_SD), the presence of at least one test-day (TD) SCC $>400,000$ cells $/ \mathrm{mL}$ in the lactation, and the ratio of number of TD SCC $>400,000$ cells/ $\mathrm{mL}$ to total number of TD in the lactation. Novel traits and lactation-mean SCS (SCS_LM) were analyzed using linear mixed or logistic regression models, including month of calving, year of calving, number of TD, and milk yield as fixed effects, and herd and residual as random terms. A multitrait linear animal model was applied to a random subset of 152 herds ( $\mathrm{n}=22,695$ cows) to assess heritability of and genetic correlations between SCC traits. Alternative SCC traits were affected by the environmental factors included in the model; in particular, results suggested a seasonal effect and a tendency toward an improvement of the udder health status in the last years. Association was also found between novel SCC traits and milk production. Alternative SCC traits exhibited coefficients of additive genetic variation that were similar to or larger than that of traditional SCS_LM. Heritability of novel SCC traits was smaller than heritability of SCS_LM (0.126 \pm 0.014 ), ranging from $0.044 \pm 0.008$ (SCS_SD) to $0.087 \pm 0.010$ (SCS_150). Genetic correlations between SCC traits ranged from $0.217 \pm 0.096$ (SCS_150 and SCS_SD) to $0.969 \pm 0.010$ (SCS_LM and SCS_150). Alternative SCC traits exhibited additive genetic varia-

Received March 26, 2018.

Accepted July 3, 2018.

${ }^{1}$ Corresponding author: giuliovisentin@anafi.it tion that is potentially exploitable in breeding programs of Italian Holstein population to improve resistance to mastitis.

Key words: mastitis, somatic cell count, novel trait, genetic selection, dairy cattle

\section{INTRODUCTION}

The wide spread and high cost of bovine mastitis, an inflammatory response of the mammary gland to an infection, continues to represent a primary concern for dairy farmers. Although environmental factors such as herd health management strongly affect the occurrence of the disease, a cow's susceptibility to mastitis is also genetically determined (Miglior et al., 2017). Thus, breeding for disease resistance represents an important strategy to decrease the incidence of mastitis in the dairy herd (Shook and Schutz, 1994; Ruegg, 2017). Over the last decades, disease-recording systems have been successfully implemented in the Scandinavian countries, allowing direct selection for improving an animal's resistance to mastitis (Heringstad et al., 2000). Efforts in recording clinical mastitis (CM) have also been made in other countries, especially Austria, Germany, France, and Canada (Egger-Danner et al., 2015). However, as routine disease-recording systems are not widespread, genetic selection for mastitis resistance is mostly based on indirect traits, the most common being log-transformed test-day SCC (TD SCS) and lactation-mean SCS (SCS_LM; Mark et al., 2002; Martin et al., 2018). Estimates of genetic correlation between somatic cells and CM range from 0.30 to 0.90 , with an average value of 0.70 (Mrode and Swanson, 1996). The non-unity genetic correlation between somatic cells and CM suggests that they are not the same trait and that indirect selection based only on SCC could be less effective than direct selection (Heringstad et al., 2000). Moreover, SCS_LM does not account for $\mathrm{SCC}$ variation over the lactation, ignoring the dynamic of mastitis events. In fact, IMI are responsible for a deviation from the typical SCC curve, which differs ac- 
cording to the type of pathogen causing the infection (de Haas et al., 2004).

Alternative traits derived from SCC have been explored recently as new indicators to genetically improve resistance to mastitis (de Haas et al., 2008; Urioste et al., 2010, 2012; Koeck et al., 2012). Novel traits include average TD SCC in early or late lactation, distribution characteristics (e.g., maximum SCC and variation in SCC curve throughout the entire lactation period), and level of infection (e.g., number of TD above predefined SCC thresholds and patterns of SCC peaks). Green et al. (2004) investigated SCC distribution during lactation and suggested that maximum SCC and standard deviation of SCC were better indicators of $\mathrm{CM}$ than was geometric mean SCC. de Haas et al. (2008) estimated genetic correlations from 0.55 to 0.93 between CM and novel SCC traits, and 0.55 to 0.98 between subclinical mastitis and novel SCC traits. The same authors (de Haas et al., 2008) concluded that the use of a combination of different SCC traits (e.g., peak patterns of SCC) was more successful in improving udder health than the traditional SCC. Similarly, Urioste et al. (2010) explored several alternative SCC traits able to better capture changes in SCC distribution, time and level of infection, and time of recovery, compared with traditional lactation-mean SCC. An important finding of the study of Urioste et al. (2010) was that traits such as standard deviation of SCC and presence of at least one TD SCC > 500,000 cells $/ \mathrm{mL}$ were good predictors of $\mathrm{CM}$ and exhibited reasonable genetic variation that could be exploited in breeding programs against mastitis. This conclusion was supported in a subsequent study (Urioste et al., 2012) in which strong genetic correlations $(>0.80)$ for alternative SCC traits with $\mathrm{CM}$ and subclinical mastitis were estimated. Koeck et al. (2012) demonstrated that, among all the SCC traits investigated, a combination of mean SCS in early lactation, standard deviation of SCS, and presence of at least one TD SCC $>500,000$ cells $/ \mathrm{mL}$ was the best predictor of mastitis resistance.

In the aforementioned studies (de Haas et al., 2008; Urioste et al., 2010, 2012; Koeck et al., 2012) and in a recent preliminary Italian study (Finocchiaro et al., 2018), CM records were included and moderate to strong genetic correlations (0.39 to 0.93 ) between CM and novel SCC traits were estimated, depending on the SCC trait involved. Therefore, the objective of the present study was to investigate environmental factors associated with alternative SCC traits and to estimate their genetic parameters, which could be exploited in genetic selection for mastitis resistance in Italian Holstein population.

\section{MATERIALS AND METHODS}

\section{Data}

Test-day milk yield, fat percentage, protein percentage, and SCC records $(\mathrm{n}=574,174)$ of 66,784 firstparity Holstein cows (20 to 40 mo of age) from 404 herds in northeast Italy were provided by the Italian Holstein Association (ANAFI, Cremona, Italy). Data collection, which occurred at approximately monthly intervals within the national routine milk recording system, took place from 1999 to 2014. Only cows between 5 and 305 DIM, with a minimum of 5 TD records and at least $3 \mathrm{TD}$ in early lactation (5 to $150 \mathrm{DIM}$ ) were included in the analysis. Furthermore, only lactations with the first TD within $60 \mathrm{~d}$ after calving and with an interval between 2 consecutive TD of $<70 \mathrm{~d}$ were considered. Following editing of the data as above, 571,111 TD records of 66,407 cows were available for statistical analysis.

\section{Definition of Alternative SCC Traits}

Test-day SCC data were log-transformed to SCS (Ali and Shook, 1980) and SCS_LM was computed for each animal. Novel traits were defined in an attempt to better capture different aspects of mastitis, particularly SCC variation and level of infection. Test-day SCS were averaged over early lactation; that is, from 5 to 150 DIM (SCS_150), as reported in Koeck et al. (2012). Following Green et al. (2004), standard deviation of SCS of the entire lactation (SCS_SD) was included in this study. Similar to de Haas et al. (2008), Urioste et al. (2010), and Koeck et al. (2012), we assumed that TD SCC exceeding a predefined threshold could indicate a mastitis event. Thus, the trait "infection" (INF) was defined as presence of at least one TD SCC $>400,000$ cells/mL in the lactation, and "severity" (SEV) was calculated as the ratio of the number of TD SCC $>400,000$ cells $/ \mathrm{mL}$ to total number of TD SCC in the lactation.

\section{Statistical Analysis}

Phenotypic Analysis. To identify factors associated with phenotypic variation of the SCC traits, SCS_LM, SCS_150, SCS_SD, and SEV were analyzed using the MIXED procedure of SAS (SAS Institute Inc., Cary, $\mathrm{NC})$ using the following linear mixed model:

$$
\begin{aligned}
y_{i j k l m n}=\mu+ & \text { Month }_{i}+\text { Year }_{j}+n t d_{k}+M Y_{l} \\
& + \text { Herd }_{m}+e_{i j k l m n},
\end{aligned}
$$


where $y_{i j k l m n}$ is the investigated SCC trait; $\mu$ is the overall mean; Month $_{i}$ is the fixed effect of the $i$ th month of calving ( $i=12$ levels); Year $_{j}$ is the fixed effect of the $j$ th year of calving ( $j=16$ levels, from 1999 to 2014$) ; n t d_{k}$ is the fixed effect of the $k$ th number of TD $(k=6$ levels, from 5 to 10); $M Y_{l}$ is the fixed effect of the $l$ th class of average daily milk yield $(l=5$ levels, class $1 \leq 19.9$ $\mathrm{kg} / \mathrm{d}, 19.9<$ class $2 \leq 25.4,25.4<$ class $3 \leq 30.9,30.9$ $<$ class $4 \leq 36.4$, class $5>36.4 \mathrm{~kg} / \mathrm{d}$, based on $0.5 \mathrm{SD}$ for the 3 central classes and 1.5 SD for the 2 extreme classes); Herd $d_{m}$ is the random effect of the $m$ th herd ( $m$ $=404$ levels); and $e_{i j k l m n}$ is the random residual. In addition, the fixed effect of age at calving was initially taken into account but was not retained in the final model because it was not statistically significant in explaining the variation of the investigated traits. Herd and residuals were assumed to have a normal distribution with zero means and variances of $\sigma_{h}^{2}$ and $\sigma_{e}^{2}$, respectively. The proportion of variance explained by herd was calculated for each trait dividing the corresponding variance component $\left(\sigma_{h}^{2}\right)$ by the total variance $\left(\sigma_{h}^{2}+\sigma_{e}^{2}\right)$. Pairwise comparisons between least squares means (LSM) were performed using the Tukey correction $(P$ $<0.05)$. The binary trait INF was analyzed by fitting a logistic regression model using the GLIMMIX procedure of SAS (SAS Institute Inc.), adjusting for the same effects described for the previous model. For each effect, the last class was accounted for as the referent, and odds ratios were considered significant when the 95\% CI did not include 1.

Genetic Analysis. Contemporary groups (HYS) were defined by combining the effects of herd, year of calving, and season of calving (classes of 3 mo each: January-March, April-June, July-September, and October-December), and HYS with fewer than 5 cows were discarded from the data set. The final data included 46,378 cows in 303 herds. To reduce computation time for genetic analysis, a random subset of 152 herds ( $\mathrm{n}=22,695$ cows) was analyzed using the VCE6 software (Neumaier and Groeneveld, 1998; Groeneveld et al., 2010). Variance and covariance components of SCC traits were obtained using a 5-trait linear animal model. The model used for each trait was as follows:

$$
y_{i j k}=\mu+H Y S_{i}+n t d_{j}+\text { Animal }_{k}+e_{i j k},
$$

where $y_{i j k}$ represents the investigated SCC traits; $\mu$ represents the overall means; $H Y S_{i}$ is the fixed effect of the $i$ th herd-year-season of calving ( $i=2,534$ levels); $n t d_{j}$ is the fixed effect of the $j$ th number of TD $(j=6$ levels, from 5 to 10); Animal $_{k}$ is the random additive genetic effect of the $k$ th animal ( $k=62,146$ individuals); and $e_{i j k}$ is the random residual. Pedigree information was provided by ANAFI and included cows with phenotypic records and all their ancestors to 4 generations back.

Although threshold models are considered more appropriate for analysis of binary traits, a linear model was applied in the present study for INF, as this approach has been previously found to be robust for genetic analysis on binary traits (Negussie et al., 2008; Koeck et al., 2010).

\section{RESULTS}

\section{Descriptive Statistics}

Holstein cows had an average milk yield of 28.19 $\mathrm{kg} / \mathrm{d}$, with a coefficient of variation of $19.5 \%$ (Table 1). Milk fat and protein averaged 3.57 and $3.31 \%$, respectively. Lactation-mean SCS ranged from -0.88 to 9.02 , with a mean of 2.86 . A slightly lower value (2.66) was reported for SCS_150, whereas SCS_SD averaged 1.29. About $47 \%$ of the cows had at least one TD SCC $>400,000$ cells $/ \mathrm{mL}$ (INF) and the ratio of number of TD SCC $>400,000$ cells $/ \mathrm{mL}$ to total number of TD SCC (SEV) averaged 0.14 (Table 1).

\section{Phenotypic Analysis}

Fixed effects included in the models were important sources of variation of the alternative SCC traits, and the proportion of variance explained by herd ranged from 6.48 to $13.25 \%$ for SCS_SD and SCS_LM, respectively (data not shown). Least squares means and corresponding standard errors of alternative SCC traits for the effect of month of calving are presented in Figure 1. Lactation-mean SCS and SCS_150 showed similar patterns, with their LSM increasing to a maximum value in May and June, and reaching a minimum in October. The LSM of SEV remained relatively constant between January and June; it then decreased until October and increased again in November and December. Cows that calved in August had the lowest variation in SCS (SCS_SD; Figure 1). The LSM of alternative SCC traits in different years of calving are reported in Figure 2. All 4 traits exhibited an erratic trend across the years, with LSM that tended to decrease starting in 2009, and particularly from 2011, according to the Tukey comparison adjustment of LSM differences. Cows with lower milk production had greater SCS, both when TD SCS were averaged over the entire lactation period and over the first $150 \mathrm{~d}$, as well as greater SCS_SD values (Figure 3). Low-producing cows had greater SEV than high-producing cows: $0.21 \pm 0.01$ and $0.13 \pm 0.01$ for cows with milk yield $\leq 19.9 \mathrm{~kg} / \mathrm{d}$ (class 1 ) and cows with milk yield $>36.4 \mathrm{~kg} / \mathrm{d}$ (class 5 ), respectively (Figure 3 ). Cows with 7 or 8 TD during the lactation had 
Table 1. Descriptive statistics of average daily milk yield, composition, SCS (SCS_LM), and alternative SCC traits in first-lactation Holstein cows $(\mathrm{n}=66,407)$

\begin{tabular}{lcccc}
\hline Trait & Mean & SD & Minimum & Maximum \\
\hline Milk yield, kg/d & 28.19 & 5.50 & 4.83 & 58.3 \\
Milk composition, $\%$ & & & & \\
Fat & 3.57 & 0.52 & 0.27 & 5.77 \\
Protein & 3.31 & 0.22 & 1.49 & 9.72 \\
SCS_LM & 2.86 & 1.37 & -0.88 & \\
Alternative SCC traits & & & & 9.31 \\
SCS_150 & 2.66 & 1.44 & -1.64 & 4.61 \\
SCS_SD & 1.29 & 0.63 & 0.07 & 1 \\
SEV & 0.14 & 0.21 & 0 & 1 \\
INF & 0.47 & 0.50 & 0 & SCS \\
\hline
\end{tabular}

${ }^{1}$ SCS_150 = average SCS in early lactation (5 to 150 DIM); SCS_SD = standard deviation of SCS of the entire lactation (5 to $305 \mathrm{DIM}$ ); SEV = ratio of the number of test-day (TD) SCC $>400,000$ cells $/ \mathrm{mL}$ to total number of TD SCC in the lactation (severity); INF = presence of at least one TD SCC $>400,000$ cells $/ \mathrm{mL}$ in the lactation (infection).

lower SCS_LM, SCS_150, and SCS_SD than cows with fewer or more TD; SEV was greater for cows with only 5 or 6 TD available (data not shown).

Odds ratio and 95\% CI for INF for different classes of fixed effects included in the logistic regression model are reported in Table 2. The last class of each effect was used as the referent. Cows that calved in the first half of the year were at greater risk of having at least one TD SCC $>400,000$ cells $/ \mathrm{mL}$, whereas cows that calved in the second part of the year were at lower risk of being scored as 1 compared with the referent (December). With the exception of calving years 2011 and 2013, cows that calved in the previous years were at greater risk of experiencing at least one peak of SCC than animals that calved in 2014. Having fewer TD data was associated with a lower risk of being scored as 1 for INF, whereas an average milk production $<30.9$ $\mathrm{kg} / \mathrm{d}$ was considered a risk factor for having SCC above the predefined threshold.

\section{Genetic Analysis}

Descriptive statistics and estimates of variance components and heritability of alternative SCC traits obtained from the random subset $(\mathrm{n}=22,695)$ are reported in Table 3. The subset was representative of the entire population analyzed at the phenotypic level, having mean and SD that were very comparable with those reported in Table 1. Heritability of novel SCC traits was smaller than the heritability of traditional SCS_LM $(0.126 \pm 0.014)$, ranging from $0.044 \pm 0.008$ (SCS_SD) to $0.087 \pm 0.010$ (SCS_150). The lowest coefficient of additive genetic variation was reported for SCS_SD (9.8\%) and the greatest for INF (25.1\%) and $\operatorname{SEV}(31.9 \%)$.

Genetic correlations between SCC traits ranged from $0.217 \pm 0.096$ (SCS_150 and SCS_SD) to 0.969 \pm 0.010 (SCS_LM and SCS_150; Table 4). Lactationmean SCS correlated strongly with alternative SCC traits, except for a moderate relationship with SCS_SD $(0.368 \pm 0.084)$. Genetic relationships of INF or SEV with other traits ranged from $0.596 \pm 0.085$ (SEV and SCS_SD) to $0.953 \pm 0.036$ (INF and SEV; Table 4).

\section{DISCUSSION}

Although recording of CM events would be an asset for dairy farm management, routine disease-recording systems are currently not widely implemented. Thus, SCC represents the most common indicator of udder health, because it is recorded at a routine level and is genetically associated with CM. Nevertheless, using a combination of different SCC traits could better describe SCC variation over time and the dynamic of infection rather than the standard TD SCS and SCS_LM, improving genetic progress in selection for mastitis resistance. In this study, we characterized 4 alternative SCC traits derived from TD SCC data in Italian Holsteins: SCS_150, SCS_SD, INF, and SEV. To date, little information on sources of variation of novel SCC traits at phenotypic level has been provided (Windig et al., 2005).

\section{Phenotypic Analysis}

The present study demonstrated that different factors can affect the variation of alternative SCC traits and should be accounted for in order to use them appropriately as a tool to implement genetic selection for mastitis resistance. The evaluation of such nongenetic sources of variation represented a first step for subsequent genetic analysis. Results from the present study relative to the effect of month of calving suggested a seasonal effect. Thus, humidity and high temperature 

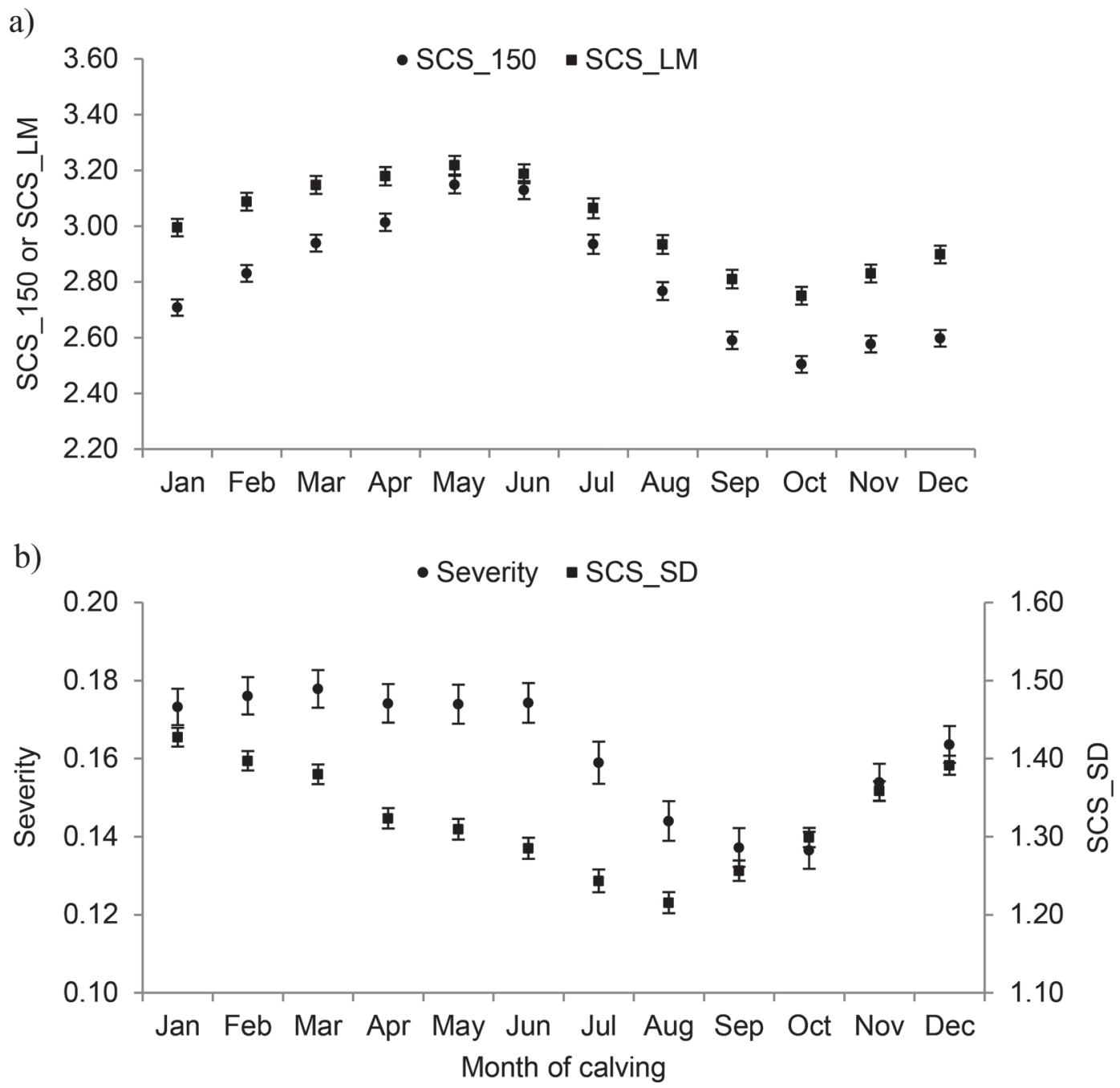

Figure 1. Least squares means and standard errors of (a) average SCS in early lactation (SCS_150) and lactation-mean SCS (SCS_LM); and (b) standard deviation of SCS of the entire lactation (SCS_SD) and ratio of the number of test-day (TD) SCC $>400,000$ cells/mL to total number of TD SCC in the lactation (severity) across month of calving.

could have increased the susceptibility of the cows to infection as well as increased bacterial counts in bedding, resulting in a greater exposure to pathogens and an increase of SCC in milk (Harmon, 1994). In fact, cows that calved from August to November (late summer-autumn) were at lower risk of having at least one TD SCC $>400,000$ cells $/ \mathrm{mL}$ (Table 2 ). As a consequence, an association was found between late summerautumn calving and lower SEV, which represents the ratio between number of TD $\mathrm{SCC}>400,000$ cells $/ \mathrm{mL}$ and the total number of TD SCC available for a given cow (Figure 1).

Although erratic trends were reported for all alternative SCC traits across the different calving years, a tendency toward an improvement of the udder health status can be observed in the last years (Table 2 and
Figure 2). Lower SCC may indicate a reduction in disease occurrence, which could result from improvement of herd management practices, housing, hygiene, feeding strategies, and milking procedures. In 2009, the Animal Health and Animal Welfare Panel of the European Food Safety Authority (EFSA, 2009) delivered a report on the effect of management, housing, and feeding on the welfare of dairy cows and udder disorders. To reduce udder infections, the use of proper stall design, as well as adequate bedding hygiene and milking procedures complying with relevant guidelines for the prevention of mastitis, was strongly recommended. Furthermore, the need to improve farm hygiene, milking, and dry cow period management was highlighted in the study conducted by Bertocchi et al. (2012). Analyzing milk samples collected between 2005 and 2011 in 
northern Italy, the authors reported a reduction in the prevalence of contagious mastitis (indicating the efficacy of control plans for contagious IMI), accompanied, on the other hand, by an increase in the prevalence of environmental pathogens.

In addition to calving month and calving year, we found an association between novel SCC traits and milk production, which can indirectly reflect the animal's health status. Cows with lower average daily milk yield that had greater SCS (Figure 3) and were at greater risk of having TD SCC $>400,000$ cells $/ \mathrm{mL}$ (Table 2) could have experienced one or more mastitis events during the lactation, negatively affecting average daily milk yield, and could be more susceptible to new infections (as supported by the greater SEV values reported in Figure 3). This would explain the negative effect of SCC on milk production, as reported in the literature (Koldeweij et al., 1999; Bobbo et al., 2016). Nevertheless, another possible explanation would be a dilution effect: as milk yield increases, SCC decreases in udders free from infection (Emanuelson and Funke, 1991; Schepers et al., 1997). These hypotheses underline the potential circularity between udder infection status, SCC, and milk production, which may confuse the cause-effect relationship (Green et al., 2006). Further research, beyond the purpose of the present study, is needed to deepen the cause-effect relationships between milk yield and new SCC traits, by using, for example, structural equation models (de los Campos et al., 2006).
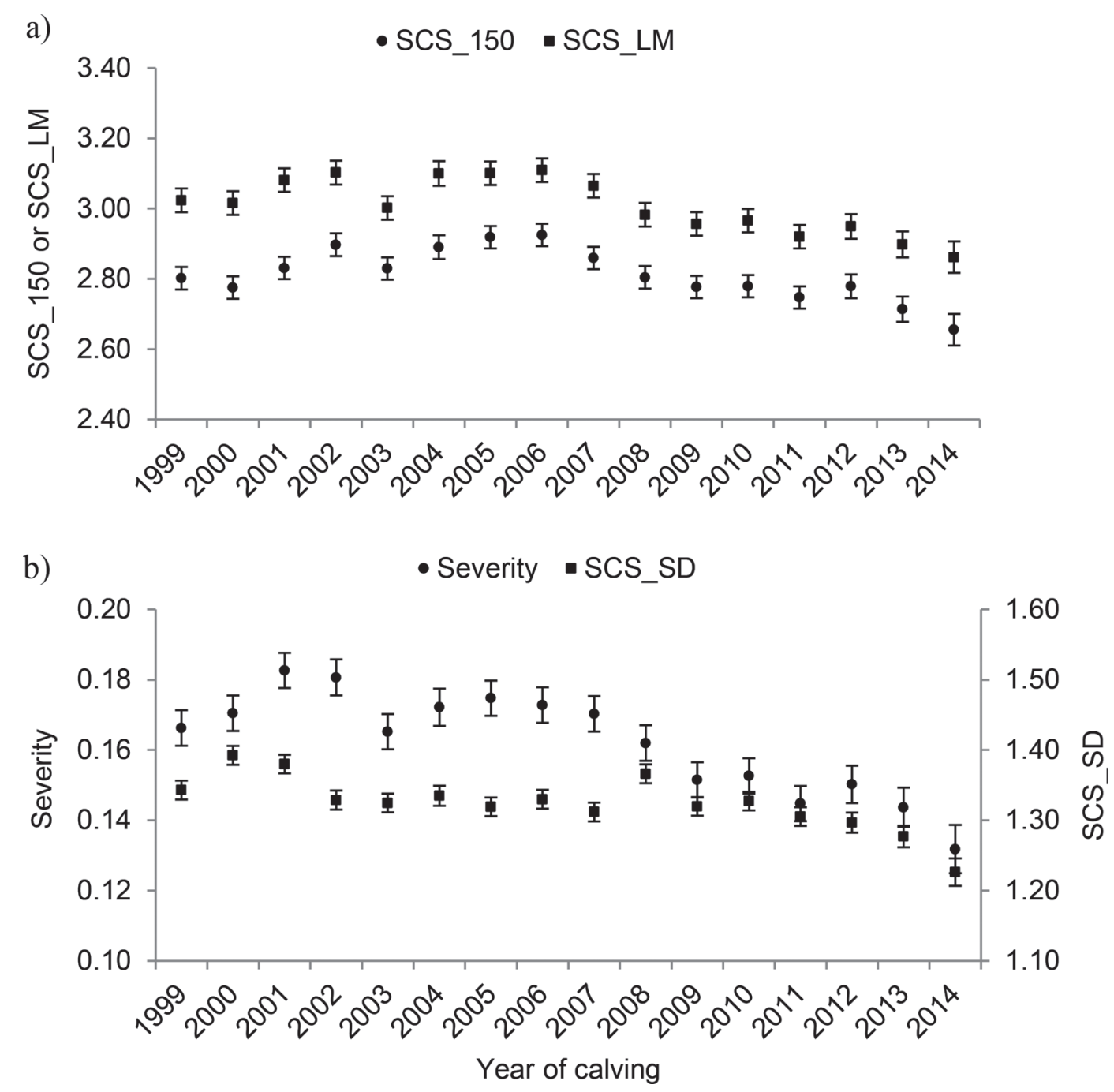

Figure 2. Least squares means and standard errors of (a) average SCS in early lactation (SCS_150) and lactation-mean SCS (SCS_LM); and (b) standard deviation of SCS of the entire lactation (SCS_SD) and ratio of the number of test-day (TD) SCC >400,000 cells/mL to total number of TD SCC in the lactation (severity) across year of calving. 


\section{Genetic Analysis}

As far as we know, few studies have investigated genetic variability of alternative SCC traits. New traits describing SCC distribution during lactation were defined by Green et al. (2004), but genetic results were not provided. Among the analyzed traits, SCC standard deviation was identified by Green et al. (2004) as a good predictor of CM. Variability in SCC during the entire lactation can be explained by a recurrence of an initial infection or appearance of a new infection in late lactation, as well as by several small challenges in quarters more susceptible to IMI (Green et al., 2004). Genetic investigation on SCC standard deviation was then performed by other authors. Urioste et al. (2010) reported heritability of 0.10 , whereas our results (Table
3 ) are in accordance with the lower estimate of 0.03 reported by Koeck et al. (2012). Another trait considered in several studies is average SCS in early lactation when cases of mastitis are more frequent. Our estimates for SCS_150 were in agreement with the results reported by de Haas et al. (2008), Urioste et al. (2010), Windig et al. (2010), and Koeck et al. (2012), with heritability ranging from 0.08 to 0.11 . Moreover, excess of TD SCC above a predefined threshold was assumed to be a potential indicator of udder infection (de Haas et al., 2008; Urioste et al., 2010; Koeck et al., 2012). In the present study, an SCC of 400,000 cells/mL (the limit applied by the European Community for bulk milk destined for human consumption) was selected as the threshold value to identify potential mastitis events. Both INF and SEV showed similar heritability of about
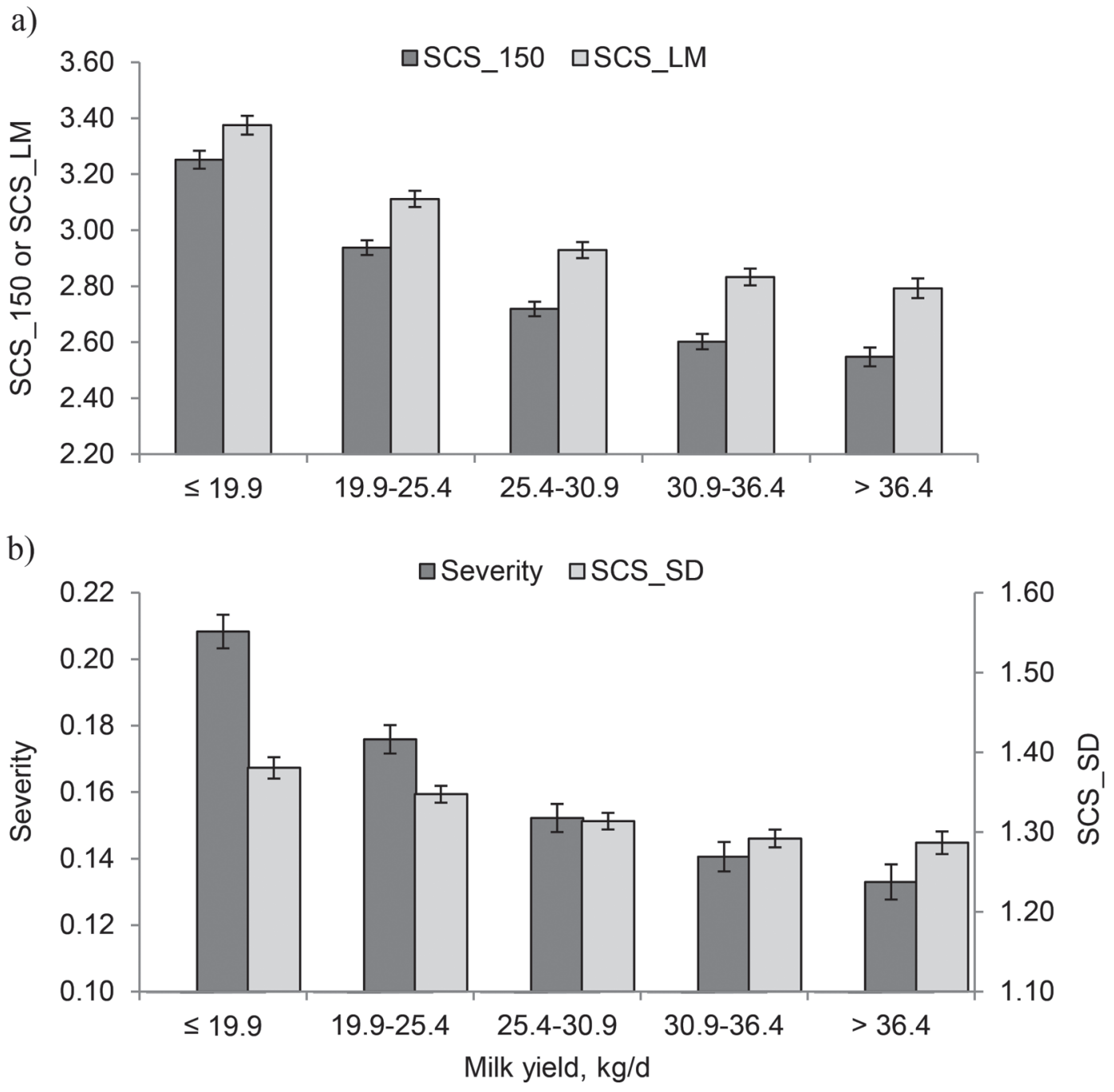

Figure 3. Least squares means and standard errors of (a) average SCS in early lactation (SCS_150) and lactation-mean SCS (SCS_LM); and (b) standard deviation of SCS of the entire lactation (SCS_SD) and ratio of the number of test-day (TD) SCC >400,000 cells/mL to total number of TD SCC in the lactation (severity) across classes of average daily milk yield. 
Table 2. Odds ratio ${ }^{1}$ with $95 \%$ confidence interval for $\mathrm{INF}^{2}$ for different classes of fixed effects compared with a reference level

\begin{tabular}{|c|c|c|}
\hline Effect & Odds ratio & $95 \%$ CI \\
\hline \multicolumn{3}{|c|}{ Month of calving } \\
\hline January & 1.12 & $1.05 ; 1.20$ \\
\hline February & 1.13 & $1.05 ; 1.22$ \\
\hline March & 1.14 & $1.06 ; 1.23$ \\
\hline April & 1.01 & $0.93 ; 1.09$ \\
\hline May & 1.12 & $1.04 ; 1.21$ \\
\hline June & 1.10 & $1.02 ; 1.19$ \\
\hline July & 0.97 & $0.88 ; 1.05$ \\
\hline August & 0.78 & $0.72 ; 0.85$ \\
\hline September & 0.77 & $0.71 ; 0.83$ \\
\hline October & 0.76 & $0.71 ; 0.82$ \\
\hline November & 0.91 & $0.85 ; 0.98$ \\
\hline December & Referent & \\
\hline \multicolumn{3}{|c|}{ Year of calving } \\
\hline 1999 & 1.34 & $1.17 ; 1.54$ \\
\hline 2000 & 1.50 & $1.30 ; 1.72$ \\
\hline 2001 & 1.54 & $1.35 ; 1.77$ \\
\hline 2002 & 1.38 & $1.20 ; 1.58$ \\
\hline 2003 & 1.29 & $1.12 ; 1.48$ \\
\hline 2004 & 1.38 & $1.20 ; 1.59$ \\
\hline 2005 & 1.36 & $1.18 ; 1.55$ \\
\hline 2006 & 1.39 & $1.21 ; 1.60$ \\
\hline 2007 & 1.38 & $1.20 ; 1.58$ \\
\hline 2008 & 1.35 & $1.18 ; 1.55$ \\
\hline 2009 & 1.20 & $1.05 ; 1.37$ \\
\hline 2010 & 1.24 & $1.08 ; 1.42$ \\
\hline 2011 & 1.12 & $0.98 ; 1.28$ \\
\hline 2012 & 1.21 & $1.06 ; 1.39$ \\
\hline 2013 & 1.07 & $0.93 ; 1.24$ \\
\hline 2014 & Referent & \\
\hline \multicolumn{3}{|c|}{ Number of test-days } \\
\hline 5 & 0.69 & $0.61 ; 0.78$ \\
\hline 6 & 0.67 & $0.60 ; 0.76$ \\
\hline 7 & 0.61 & $0.56 ; 0.67$ \\
\hline 8 & 0.68 & $0.63 ; 0.72$ \\
\hline 9 & 0.81 & $0.76 ; 0.86$ \\
\hline 10 & Referent & \\
\hline \multicolumn{3}{|c|}{ Milk yield, $\mathrm{kg} / \mathrm{d}$} \\
\hline$\leq 19.9$ & 1.67 & $1.51 ; 1.85$ \\
\hline$\overline{19} .9$ to 25.4 & 1.27 & $1.18 ; 1.38$ \\
\hline 25.4 to 30.9 & 1.08 & $1.00 ; 1.16$ \\
\hline 30.9 to 36.4 & 0.98 & $0.91 ; 1.06$ \\
\hline$>36.4$ & Referent & \\
\hline
\end{tabular}

${ }^{1}$ Odds ratio for month of calving, year of calving, number of test-days, and milk yield compare the likelihood of infection of each level of risk factor relative to the last level (i.e., referent).

${ }^{2} \mathrm{INF}=$ presence of at least one test-day $\mathrm{SCC}>400,000$ cells $/ \mathrm{mL}$ in the lactation (infection).
0.05 to 0.06 (Table 3 ). A different threshold was used to define the binary trait TD $>500$ (presence of TD SCC $>500,000$ cells $/ \mathrm{mL}$ ) by Urioste et al. (2010) and Koeck et al. (2012), who reported heritability estimates of 0.12 and 0.03 , respectively. Presence of at least one TD SCC $>150,000$ cells $/ \mathrm{mL}$ was found to have heritability of about 0.06 to 0.07 , whereas proportion of TD SCC $>150,000$ cells $/ \mathrm{mL}$ (a trait similar to our SEV trait but with a different threshold) had heritability ranging from 0.08 to 0.11 (de Haas et al., 2008; Windig et al., 2010). However, this comparison suffers from the fact that heritability of binary traits estimated from linear models are frequency dependent and cannot be directly compared.

To the best of our knowledge, genetic correlations among alternative SCC traits have been reported in only few studies (Windig et al., 2010; Koeck et al., 2012; Urioste et al., 2012), where slightly different traits were analyzed by bivariate analyses, thus making our results difficult to compare with the existing literature. In the present study, the traditional SCS_LM was strongly correlated with all the novel SCS traits, except for SCS_SD. Similar results were reported by de Haas et al. (2008), who estimated genetic correlations of average TD SCS up to 335 DIM with SCS in early lactation, presence of at least one TD SCC $>150,000$ cells/mL, and proportion of TD SCC $>150,000$ cells/ $\mathrm{mL}$ that were $\geq 0.95$. In our study, the trait SCS_SD was also weakly correlated with SCS_150 (0.217), whereas a genetic correlation $\geq 0.60$ was observed with both INF and SEV. Our findings are in accordance with the genetic correlation coefficients reported by Koeck et al. (2012): 0.29 between SCS standard deviation and SCS in early lactation, and 0.66 between SCS standard deviation and presence of TD SCC $>500,000$ cells $/ \mathrm{mL}$. Nevertheless, these results contrast with the estimates of 0.97 between SCS standard deviation and SCS in early lactation, and 0.94 between SCS standard deviation and presence of TD SCC $>500,000$ cells $/ \mathrm{mL}$ reported by Urioste et al. (2012). Among the novel

Table 3. Descriptive statistics, estimated additive genetic variance $\left(\sigma_{a}^{2}\right)$, residual variance $\left(\sigma_{e}^{2}\right)$, coefficient of additive genetic variation $\left(\mathrm{CV}_{\mathrm{a}}\right)$, and heritability $\left(\mathrm{h}^{2} ; \mathrm{SE}\right.$ in parentheses) of lactation-mean SCS and alternative SCC traits in first-lactation Holstein cows $(\mathrm{n}=22,695)$

\begin{tabular}{lccccccrr}
\hline Trait $^{1}$ & Mean & SD & Minimum & Maximum & $\sigma_{a}^{2}$ & $\sigma_{e}^{2}$ & $\mathrm{CV}_{\mathrm{a}}, \%$ & $\mathrm{~h}^{2}$ \\
\hline SCS_LM & 2.79 & 1.35 & -0.74 & 9.00 & 0.189 & 1.316 & 15.6 & $0.126(0.014)$ \\
SCS_150 & 2.61 & 1.42 & -0.93 & 9.31 & 0.151 & 1.586 & 14.9 \\
SCS_SD & 1.26 & 0.62 & 0.07 & 4.09 & 0.015 & 0.332 & 9.8 & $0.087(0.010)$ \\
INF & 0.45 & 0.50 & 0 & 1 & 0.013 & 0.210 & 25.1 & $0.057(0.008)$ \\
SEV & 0.13 & 0.21 & 0 & 1 & 0.002 & 0.035 & 31.9 & $0.047(0.010)$ \\
\hline
\end{tabular}

${ }^{1}$ SCS_LM = lactation-mean SCS; SCS_150 = average SCS in early lactation (5 to 150 DIM); SCS_SD = standard deviation of SCS of the entire lactation (5 to $305 \mathrm{DIM}$ ); INF = presence of at least one test-day (TD) SCC >400,000 cells $/ \mathrm{mL}$ in the lactation (infection); SEV = ratio of the number of TD SCC $>400,000$ cells/mL to total number of TD SCC in the lactation (severity). 
Table 4. Genetic (above diagonal; SE in parentheses) and phenotypic (below diagonal) correlations between SCC traits in first-lactation Holstein cows

\begin{tabular}{|c|c|c|c|c|c|}
\hline Trait $^{1}$ & SCS_LM & SCS150 & SCS_SD & INF & SEV \\
\hline$\overline{\text { SCS_LM }}$ & - & $0.969(0.010)$ & $0.368(0.084)$ & $0.889(0.031)$ & $0.945(0.021)$ \\
\hline SCS_150 & 0.894 & - & $0.217(0.096)$ & $0.808(0.044)$ & $0.852(0.041)$ \\
\hline SCS_SD & 0.299 & 0.199 & - & $0.747(0.041)$ & $0.596(0.085)$ \\
\hline INF & 0.610 & 0.535 & 0.644 & - & $0.953(0.036)$ \\
\hline SEV & 0.793 & 0.700 & 0.423 & 0.664 & - \\
\hline
\end{tabular}

${ }^{1}$ SCS_LM $=$ lactation-mean SCS; SCS_150 = average SCS in early lactation (5 to 150 DIM); SCS_SD = standard deviation of SCS of the entire lactation (5 to 305 DIM); INF = presence of at least one test-day (TD) $\mathrm{SCC}>400,000$ cells $/ \mathrm{mL}$ in the lactation (infection); $\mathrm{SEV}=$ ratio of the number of TD SCC $>400,000$ cells/ $\mathrm{mL}$ to total number of TD SCC in the lactation (severity).

traits, SCS_150 was more strongly correlated with INF and SEV, showing coefficients of genetic correlation $>0.80$. This is in agreement with the values of 0.88 and 0.94 for SCS in early lactation and presence of TD SCC >500,000 cells/mL reported by Koeck et al. (2012) and Urioste et al. (2012), respectively. Also, the presence of TD SCC $>150,000$ cells $/ \mathrm{mL}$ and proportion of TD SCC $>150,000$ cells $/ \mathrm{mL}$ had genetic correlations with SCS in early lactation $>0.90$ (Windig et al., 2010). As expected, a strong genetic correlation (0.953) was estimated between INF and SEV, traits both based on presence of TD SCC $>400,000$ cells $/ \mathrm{mL}$. This is consistent with the strong genetic correlation (0.977) reported by Windig et al. (2010) between "Suspect" and "Extent," 2 traits defined as our INF and SEV, using an SCC threshold of 150,000 cells $/ \mathrm{mL}$.

\section{CONCLUSIONS}

In the present study, we identified environmental factors associated with phenotypic variation of alternative SCC traits, which should be considered to undertake the estimation of animals' genetic merit for such traits in the national breeding program. All investigated traits exhibited additive genetic variation that was similar to or greater than that of lactation-mean SCS. Moreover, all alternative SCC traits were heritable and they were moderately to strongly genetically associated among each other. Future work is needed to assess the association between the new SCC traits and CM events to develop an aggregate selection index for the reduction of mastitis susceptibility in Holstein cows.

\section{ACKNOWLEDGMENTS}

This study was supported by "Latteco project," sottomisura 10.2 of the PSRN-Biodiversity 2014-2020 and by the University of Padova (Ricerca Scientifica fondi DOR - 2016, project DOR1609108/16, Italy).

\section{REFERENCES}

Ali, A. K. A., and G. E. Shook. 1980. An optimum transformation for somatic cell concentration in milk. J. Dairy Sci. 63:487-490.

Bertocchi, L., F. Vismara, T. Hathaway, F. Fusi, A. Scalvenzi, G. Bolzoni, G. Zanardi, and G. Varisco. 2012. Evoluzione dell'eziologia della mastite bovina nel Nord Italia dal 2005 al 2011 (Evolution of the aetiology of bovine mastitis in Northern Italy from 2005 to 2011). Large Anim. Rev. 18:51-58.

Bobbo, T., C. Cipolat-Gotet, G. Bittante, and A. Cecchinato. 2016 The nonlinear effect of somatic cell count on milk composition, coagulation properties, curd firmness modeling, cheese yield, and curd nutrient recovery. J. Dairy Sci. 99:5104-5119.

de Haas, Y., W. Ouweltjes, J. ten Napel, J. J. Windig, and G. de Jong. 2008. Alternative somatic cell count traits as mastitis indicators for genetic selection. J. Dairy Sci. 91:2501-2511.

de Haas, Y., R. F. Veerkamp, H. W. Barkema, Y. T. Grohn, and Y. H. Schukken. 2004. Associations between pathogen-specific cases of clinical mastitis and somatic cell count patterns. J. Dairy Sci. $87: 95-105$.

de los Campos, G., D. Gianola, and B. Heringstad. 2006. A structural equation model for describing relationships between somatic cell count and milk yield in first-lactation dairy cows. J. Dairy Sci. $89: 4445-4455$.

Egger-Danner, C., J. Cole, J. Pryce, N. Gengler, B. Heringstad, A. Bradley, and K. Stock. 2015. Invited review: Overview of new traits and phenotyping strategies in dairy cattle with a focus on functional traits. Animal 9:191-207.

Emanuelson, U., and H. Funke. 1991. Effect of milk yield on relationship between bulk milk somatic cell count and prevalence of mastitis. J. Dairy Sci. 74:2479-2483.

European Food Safety Authority (EFSA). 2009. Scientific opinion of the panel on animal health and welfare on a request from the commission on the risk assessment of the impact of housing, nutrition and feeding, management and genetic selection on udder problems in dairy cows. EFSA J. 1141:1-60.

Finocchiaro, R., G. Visentin, M. Penasa, J. B. C. H. M. van Kaam, M. Marusi, G. Civati, and M. Cassandro. 2018. Alternative use of somatic cells counts in genetic selection for mastitis resistance: A new estimated breeding value for Italian Holstein breed. Interbull Bull. 53:31-33.

Green, L. E., Y. H. Schukken, and M. J. Green. 2006. On distinguishing cause and consequence: Do high somatic cell counts lead to lower milk yield or does high milk yield lead to lower somatic cell count. Prev. Vet. Med. 76:74-89.

Green, M. J., L. E. Green, Y. H. Schukken, A. J. Bradley, E. J. Peeler, H. W. Barkema, Y. de Haas, V. J. Collis, and G. F. Medley. 2004 Somatic cell count distributions during lactation predict clinical mastitis. J. Dairy Sci. 87:1256-1264.

Groeneveld, E., M. Kovač, and N. Mielenz. 2010. VCE User's Guide and Reference Manual, version 6.0. Institute of Farm Animal Genetics, Neustadt, Germany. ftp://ftp.tzv.fal.de/pub/vce6/doc/ vce6-manual-3.1-A4.pdf. 
Harmon, R. J. 1994. Physiology of mastitis and factors affecting somatic cell counts. J. Dairy Sci. 77:2103-2112.

Heringstad, B., G. Klemetsdal, and J. Ruane. 2000. Selection for mastitis resistance in dairy cattle: A review with focus on the situation in the Nordic countries. Livest. Prod. Sci. 64:95-106.

Koeck, A., B. Heringstad, C. Egger-Danner, C. Fuerst, and B. FuerstWaltl. 2010. Comparison of different models for genetic analysis of clinical mastitis in Austrian Fleckvieh dual-purpose cows. J. Dairy Sci. 93:4351-4358.

Koeck, A., F. Miglior, D. F. Kelton, and F. S. Schenkel. 2012. Alternative somatic cell count traits to improve mastitis resistance in Canadian Holsteins. J. Dairy Sci. 95:432-439.

Koldeweij, E., U. Emanuelson, and L. Janson. 1999. Relation of milk production loss to somatic cell count. Acta Vet. Scand. 40:47-56.

Mark, T., W. F. Fikse, U. Emanuelson, and J. Philipsson. 2002. International genetic evaluations of Holstein sires for milk somatic cell and clinical mastitis. J. Dairy Sci. 85:2384-2392.

Martin, P., H. W. Barkema, L. F. Brito, S. G. Narayana, and F. Miglior. 2018. Symposium review: Novel strategies to genetically improve mastitis resistance in dairy cattle. J. Dairy Sci. 101:27242736.

Miglior, F., A. Fleming, F. Malchiodi, L. F. Brito, P. Martin, and C. F. Baes. 2017. A 100-Year Review: Identification and genetic selection of economically important traits in dairy cattle. J. Dairy Sci. 100:10251-10271

Mrode, R. A., and G. J. T. Swanson. 1996. Genetic and statistical properties of somatic cell count and its suitability as an indirect means of reducing the incidence of mastitis in dairy cattle. Anim. Breed. Abstr. 64:847-857.
Negussie, E., I. Strandén, and E. A. Mäntysaari. 2008. Genetic analysis of liability to clinical mastitis, with somatic cell score and production traits using bivariate threshold-linear and linear-linear models. Livest. Sci. 117:52-59.

Neumaier, A., and E. Groeneveld. 1998. Restricted maximum likelihood estimation of covariances in sparse linear models. Genet. Sel Evol. 30:3-26.

Ruegg, P. L. 2017. A 100-Year Review: Mastitis detection, management, and prevention. J. Dairy Sci. 100:10381-10397.

Schepers, A. J., T. J. Lam, Y. H. Schukken, J. B. Wilmink, and W. J. Hanekamp. 1997. Estimation of variance components for somatic cell counts to determine thresholds for uninfected quarters. J. Dairy Sci. 80:1833-1840.

Shook, G. E., and M. M. Schutz. 1994. Selection on somatic cell score to improve resistance to mastitis in the United States. J. Dairy Sci. 77:648-658.

Urioste, J. I., J. Franzén, and E. Strandberg. 2010. Phenotypic and genetic characterization of novel somatic cell count traits from weekly or monthly observations. J. Dairy Sci. 93:5930-5941.

Urioste, J. I., J. Franzén, J. J. Windig, and E. Strandberg. 2012. Genetic relationships among mastitis and alternative somatic cell count traits in the first three lactations of Swedish Holsteins. J. Dairy Sci. 95:3428-3434.

Windig, J. J., M. P. L. Calus, and R. F. Veerkamp. 2005. Influence of herd environment on health and fertility and their relationship with milk production. J. Dairy Sci. 88:335-347.

Windig, J. J., W. Ouweltjes, J. ten Napel, G. de Jong, R. F. Veerkamp, and Y. de Haas. 2010. Combining somatic cell count traits for optimal selection against mastitis. J. Dairy Sci. 93:1690-1701. 